Tropical Journal of Pharmaceutical Research July 2019; 18 (7): 1559-1564

ISSN: $1596-5996$ (print); 1596-9827 (electronic)

(C) Pharmacotherapy Group, Faculty of Pharmacy, University of Benin, Benin City, 300001 Nigeria.

\title{
Ethno-pharmacological review on the wild edible medicinal plant, Lilium martagon L
}

\author{
Dmitry Olegovich Bokov ${ }^{1,2 *}$, Aleksandr Nikolaevich Luferov ${ }^{1}$, Ivan Ivanovich \\ Krasnyuk (Jnr) ${ }^{3}$, Vladimir Vladimirovich Bessonov ${ }^{2}$ \\ ${ }^{1}$ Sechenov First Moscow State Medical University, Department of Pharmaceutical and Natural Sciences, 8, Trubetskaya St, \\ Moscow 119991, ${ }^{2}$ Federal Research Center for Nutrition, Biotechnology and Food Safety, Laboratory of Food Chemistry, 2/14, \\ Ustyinsky Pr, Moscow 109240, ${ }^{3}$ Sechenov First Moscow State Medical University, Department of Analytical, Physical and \\ Colloid Chemistry, 8, Trubetskaya St, Moscow 119991, Russian Federation
}

*For correspondence: Email: fmmsu@mail.ru; Tel: +7-925-358-84-27

\begin{abstract}
Purpose: Martagon lily (Lilium martagon L.) is used in Eastern traditional medicine for wound healing and treatment of toothache. This review is intended to provide a comprehensive and critical evaluation of the chemical, botanical, ethnological, pharmacological, and pharmacognostic aspects of L. martagon, with a view to facilitating further in-depth pharmaceutical studies on the potentials of the plant as a herbal remedy.

Methods: Diverse electronic search engines and specialized reference tools such as Google, Google Scholar, Scopus, Web of Science, scientific literature, publishing sites and electronic databases (Pubmed, Springer, Wiley and Science Direct) were used for data retrieval. The data focused on botany, traditional uses, biological activities and phytochemistry of L. martagon, with emphasis on integration of this plant in official medicare.

Results: Lilium martagon possesses anti-inflammatory, sedative, anticancer, analgesic and hemostatic properties. Some modern techniques (in vitro propagation, genetic manipulation and advanced molecular biology techniques) have been applied in L. martagon biotechnology, with respect to major plant diseases and genetic variation issues.

Conclusion: Lilium martagon L contains different groups of biologically-active substances, amongst which are pyrroline derivatives and steroidal saponins. These may justify the usage of this plant and its subspecies in the traditional treatment of a wide spectrum of diseases.
\end{abstract}

Keywords: Lilium martagon, Pyrroline derivatives, Lilidine, Jatropham, Steroidal saponins, $y$-methylene glutainic acid

This is an Open Access article that uses a fund-ing model which does not charge readers or their institutions for access and distributed under the terms of the Creative Commons Attribution License (http://creativecommons.org/licenses/by/4.0) and the Budapest Open Access Initiative (http://www.budapestopenaccessinitiative.org/read), which permit unrestricted use, distribution, and reproduction in any medium, provided the original work is properly credited.

Tropical Journal of Pharmaceutical Research is indexed by Science Citation Index (SciSearch), Scopus, International Pharmaceutical Abstract, Chemical Abstracts, Embase, Index Copernicus, EBSCO, African Index Medicus, JournalSeek, Journal Citation Reports/Science Edition, Directory of Open Access Journals (DOAJ), African Journal Online, Bioline International, Open-J-Gate and Pharmacy Abstracts

\section{INTRODUCTION}

Lilium martagon L., syn. Lilium versicolor Salisb. (martagon lily [1] or Turk's cap lily), is a representative of Eurasian lily species, genus
Lilium consisting of approximately 100 species. It is native to a widespread area covering the Portuguese Republic, the whole Europe and Asia region, and Mongolia in the Far East [2]. Numerous names have been suggested for 
varieties and subspecies of the plant. However, only two of these names are considered by the World Checklist [3]. The name "Turk's cap lily", also related to several other species, came from the characteristic shape of the petals. "Martagon" is a specific epithet, a Turkish word that also means cap or turban [4]. Other names are "royal curls" ("carskie kudri" in Russian) [5], and "sarana" [6]. The systematics of the L. martagon forms includes the names: L. caucasicum (Miscz. ex Grossh.) Grossh, Caucasian lily $[=L$. martagon var. martagon], L. martagon subsp. caucasicum Miscz. ex Grossh. [= L. martagon var. martagon], L. martagon ssp. pilosiusculum (Freyn) Miscz. ex Iljin, L. martagon ssp. sooianum Priszter, and L. martagon b. pilosiusculum Freyn $[7,8]$.

The juice of the bulb of martagon lily has for long been used as a medicinal plant in traditional medicine in China, Tibet, Mongolia, Buryatia, Yakutia, Siberia, and the Far East, for wound healing, and as infusion for treating toothache [8]. Traditionally, L. martagon has food value: it is consumed raw, or in the boiled, fried or dried state, and as a seasoning [9]. The bulbs are edible. In Siberia, they are eaten raw or baked in hot ash, or boiled with milk and butter. The dried bulbs of this plant and other species of lilies are used by Yakuts in the flour form for cooking milk porridge, and Kyrgyz use the bulbs to season sheep cheese [10]. Cultivars of lily martagon have for long been used in ornamental gardening [11-13].

\section{METHODS}

Diverse electronic and scientific search engines, and specialized reference tools such as Google, Google Scholar, Scopus, Web of Science, scientific literature, publishing sites, electronic databases (Pubmed, Springer and Wiley and Science Direct) were used in the search for relevant literature. In addition, a systematic search in online research libraries such as Elibrary and specific ethnopharmacological publications was carried out in order to get exhaustive data on the medicinal uses of L. martagon.

\section{FINDINGS}

\section{Botanical characteristics of $L$. martagon}

Lilium martagon is widely distributed in the area from Europe to North Asia. The habitat of L. martagon is the mountainous area located in the European part of Russia, in the Carpathians, in Transcarpathia, and in the south of Western and Eastern Siberia. It grows on the slopes of mountains, and on edges, glades and meadows. Lilium martagon occurs singly in mixed, deciduous and small-leafed forests on rich medium-moistened soils in the mountains - from the lower to the upper mountain belt [8]. It grows individually in mixed, broadleaf forests, glades and forest edges, among shrubs in dense grass stand, but does not form continuous dense stands anywhere [14].

Lilium martagon is a perennial herb that grows up to 30 to $150 \mathrm{~cm}$ in height (occasionally it reaches $200 \mathrm{~cm}$ ). The bulb is about $8 \mathrm{~cm}$ in diameter [15]. It is formed by yellow fleshy scaly leaves. The stem is round, usually with red spots. Oblong median leaves are collected in whorls of five or six pieces, with the next leaves located higher along the stalk. The lanceolate leaves are about $15 \mathrm{~cm}$ long and $5 \mathrm{~cm}$ wide, with smooth edges. The flowers are drooping in few-flowered racemes. Flower diagram is ${ }^{*} \mathrm{P}_{3+3} \mathrm{~A}_{3+3} \mathrm{G}_{(3)}$. The perianth is purple with dark purple spots. However, sometimes, Lilium martagon plants with varied colors are seen - from white to almost black. The perianth segments are $3-4$ $\mathrm{cm}$ long, and are bent back from the base. The stamens are with purple anthers. Blooming occurs yearly from June through July. In an open place (on a sunny glade), for example, up to twenty flowers are formed on a plant.

The fruit is a six-sided capsule. The seeds are triangular and flat, with membranous edges, and light or dark brown in color, $7.88 \pm 0.76 \mathrm{~mm}$ long and $6.05 \pm 0.49 \mathrm{~mm}$ wide, with endosperm. The germ is cylindrical, straight, and poorly differentiated [8,16-19]. The pollen grains have a single furrow, with length of 59.2-85.7 $\mu$, width of 37.7-60.3 $\mu$, furrow width of $8.6-15.9 \mu$, and exine thickness of $1.4-2.5 \mu$ [20]. The chromosome number of $L$. martagon is $2 \mathrm{n}=24$ [21].

Interestingly, the fusion of one sperm cell with an egg cell for formation of embryo, and fusion of another sperm cell with a polar fusion nucleus to form endosperm (double fertilization) was discovered in lily plants in 1898, especially in L. martagon and Fritillaria tenella M.Bieb. (Fritillaria orientalis Adams) [22]. The formation of the sexual nuclei was described by Sargant in $1896-1897[23,24]$.

Lilium martagon ssp. pilosiusculum (Freyn) Miscz. ex Iljin differs from its close European species Lilium martagon L. by lanceolate (not reversely ovoid) leaves, and lanceolate (not linear) bracts, which, like the sepals, are strongly pubescent [12]. Numerous martagon lily hybrids with various flower colors are known [25-27]. 

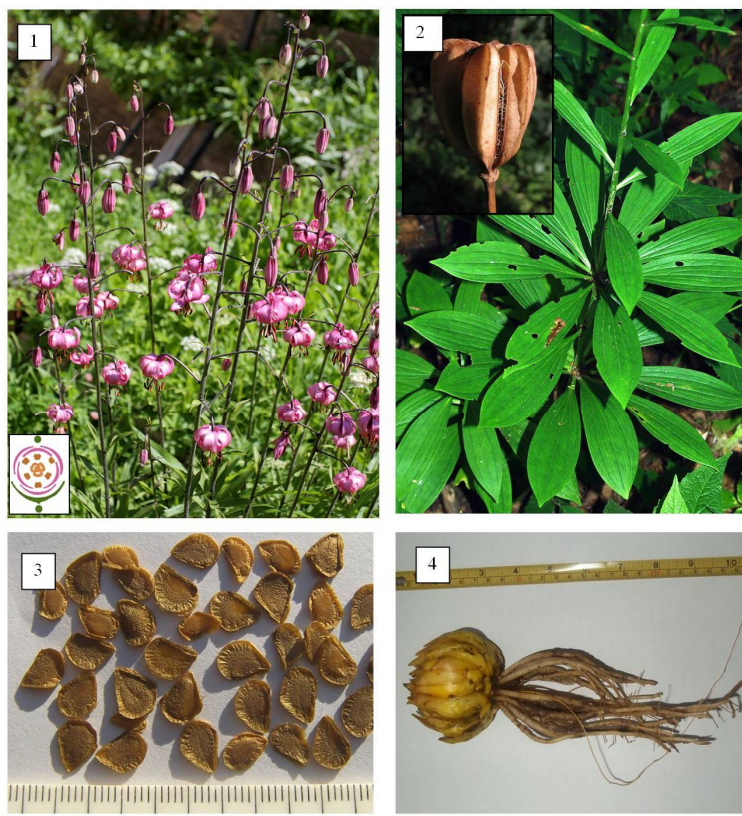

Figure 1: Lilium martagon L.: (1) upper part of the stem, inflorescence with floral diagram in flowering period; (2) upper part of the stem and capsule after flowering period; (3) seeds; and (4) closed bulb with roots $[8,33]$.

\section{Genotype characteristics of L. martagon}

Genetic variations within Sweden populations and relatedness among L. martagon populations have been estimated using random amplified polymorphic DNA (RAPD) markers. The studied populations were unexpectedly heterogeneous, notwithstanding the limited population size. There is a remarkable correlation between gene diversity and population size: larger populations have higher gene diversity level than smaller populations. Domesticated L. martagon has high levels of intra-population variability [28]. European lilies (including martagon section) were investigated for molecular phylogeny and DNA levels. Different sections were easily distinguished with rpS4-trnT-trnL, ITS sequences and assessments of genome size, whereas an exceedingly low genetic differentiation was found at a sub-sectional level [29]. Genotype diversity varied according to distribution and location [30].

\section{Composition of biologically-active compounds in L. martagon}

The chemical composition of the martagon lily has so far not received much research attention. The presence of alkaloids in all parts of the plant, as well as saponins and flavonoids in the aerial parts, have been established. The bulbs contain large amount of proteins, mucous substances, vitamins, sugars, iron and boron [31-33].
Lilidine, syn. jatropham (1) (5-hydroxy-3-methyl1, 5-dihydro-pyrrol-2-one) was isolated from the epigeal part of L. martagon in 1987 (Figure 2) $[36,37]$. Studies on the total alkaloid content (TAC) of L. martagon plants growing in the highmountain part of South Urals [Kuyantau (Malyi Yamantau) region] revealed values of $0.0063-$ $0.160 \%$ in the aerial part, and $0.150-0.358 \%$ in the bulbs, with maximum TAC at the beginning of vegetation period (April) [35].

In underground and aerial parts of the plant, $\mathrm{Y}$ methylene glutamic acid (2) is accumulated at the highest concentration, as revealed from TLC analysis of plants at different vegetative periods (at initial growth period, during growth, at the beginning of flowering, and flowering statge) in Cuneo (Italy) in the spring-summer period [36].

Researchers (TUPLS, Tokyo, Japan) have isolated several compounds from the methanol extracts of L. martagon fresh bulbs using e chromatographic separation technique. These compounds are 3,6'-di-O-feruloyl sucrose (3),

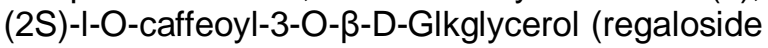
C) (4), jatropham (1), jatropham 5-O- $\beta-D-G l k(5)$ and jatropham 5-O-[O- $\beta$-D-Glk- $(1 \rightarrow 3)-\beta-D-G l k$ (6); phenylpropanoid ester of a pyrroline derivative (-)-5-hydroxy-3-methyl-3-pyrrolin-2one 5-O-(6-O-p-coumaroyl- $\beta$-D-Glk) (7), and two new steroidal saponins (25S)-spirost-5-ene$3 \beta, 17 \alpha, \quad 27-$ triol $3-O-\{O-\beta-D-G l k-(1 \rightarrow 2)-O-\beta-D-$ Glk-(1 $\rightarrow 4)-\beta-D-G l k\}$ (8) and (25S)-5aspirostane-3 $\beta, 17 \alpha, 27-$ triol 3-O-\{O- $\beta$-D-Glk$(1 \rightarrow 2)-O-\beta-D-G l k-(1 \rightarrow 4)-\beta-D-G l k\}(9)$ [37-39].

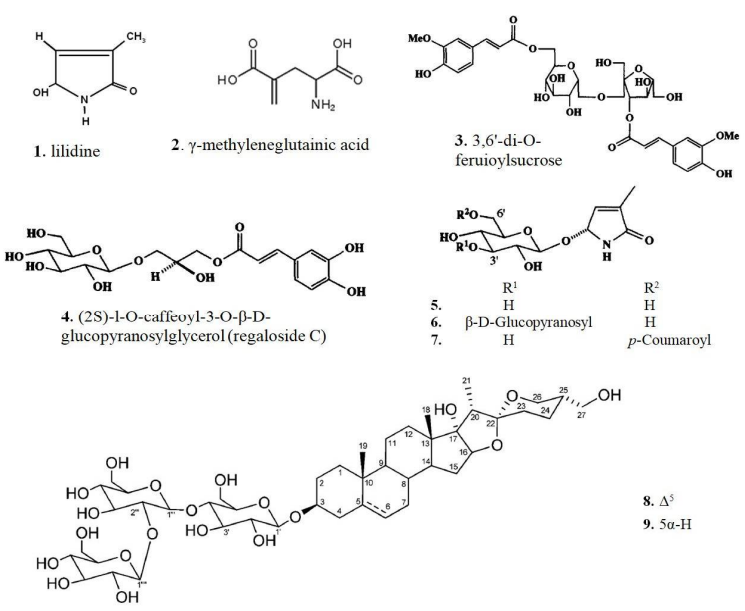

Figure 2: Structures of compounds isolated from L. martagon

Caffeic acid, limonene, indole carbinol, $\alpha-$ carotene-5, 6-epoxide, dioxin, and xanthophyllrelated pigment were isolated from the pollen of L. martagon [39]. 
Biological activities and ethno-pharmacological uses of $L$. martagon

The bulbs, stems, leaves, and flowers of L. martagon are used as medicinal raw materials. The juice of $L$. martagon is used for the healing of external wounds and stomach ulcers. The bulbs are crushed and cooked with flour for use in opening of boils. Preparations of L. martagon have anti-inflammatory, sedative, analgesic and hemostatic properties, and are used for treating gynecological diseases. Lily bulbs are widely used for treating inflammation of the rectum and bladder, and as effective anti-hemorrhoidal agents. The flower infusion is used for treating gallbladder diseases [10]. Moreover, L. martagon is popular for its used in treating cancers [40]. Extracts of L. martagon are beneficial in the inhibition of melanin synthesis in skin epidermal tissues, and also for skin lightening [41].

The pollen grains of $L$. martagon are non-allergic, but in some cases, specifically when exposed to diesel particulate matter (DPM), they may cause symptoms of allergy in sensitized individuals. The DPM induces new allergenic proteins, carries allergen molecules, acts as adjuvant for allergens, and mediates particle agglomeration on the pollen surface [42].

\section{Propagation methods and challenges in cultivating $L$. martagon}

In garden practice, two diseases of lilies often occur. One of these diseases affects many types of lilies, and is caused by the microscopic fungus botrytis (Botrytis ellyptica) [43]. This fungus disease is often confused with a viral lily disease known as a lily mosaic virus [44]. The other disease is lily symptomless virus (LSV) which is manifested in stunting and symptom of interveinal chlorosis resembling a nutrient deficiency [45]. Clover phyilody phytoplasma was identified at the molecular level in L. martagon growing in West Bohemia, with appearance characterized by unusual malformation (very flattened stem) [46].

Martagon lilies are being grown with traditional methods (bulbs and seeds) and biotechnology methods. Cultivation of L. martagon from the bulb is a very slow process, and it can produce only 3-5 plants from one bulb. In contrast, cultivation from the seeds provides growing lilies more easily and in greater amounts; hundreds of seeds can be obtained from a single lily [47].

Parts of L. martagon bulbs (nail-like scales) have meristematic reproduction ability and can be used for breeding purposes [48]. Tissue culture has become successful as an alternative to vegetative reproduction, and the plant can be grown using modern plant tissue culture methods [11].

Some modern techniques such as in vitro propagation, genetic manipulation and advanced molecular biology techniques in plant biotechnology have been successfully implemented in martagon lilies [55-58]. These techniques make it possible to propagate and produce new phenotypes. Efficient in vitro culture protocols allow for quick multiplication of lilies and accelerate breeding programs [62-65]. In view of the fact that L. martagon is an endangered species [63], it has been successfully propagated using callus culture by somatic embryogenesis. Besides, modern in vitro culture methods play a critical part the protection of this rare species [64]. Different strategies for cryopreservation of the seeds have been proposed for protecting L. martagon plants ex situ [65].

\section{CONCLUDING REMARKS}

Lilium martagon possesses different groups of biologically-active compounds such as alkaloids, flavonoids, steroidal saponins and amino acids. Herbal drugs prepared from $L$. martagon possess anti-inflammatory, sedative, anticancer, analgesic and hemostatic properties. To establish the relationship between chemical composition of $L$. martagon and its pharmacological effect, more studies need to be carried out. It is expected that this plant with a rich history of traditional medicinal usage and great potential, will soon take its place among the pharmacopoeial species.

\section{DECLARATIONS}

\section{Acknowledgement}

This study was supported by Russian Academic Excellence Project 5-100.

\section{Conflict of interest}

No conflict of interest is associated with this work.

\section{Contribution of authors}

We declare that this work was done by the authors named in this manuscript, and all liabilities pertaining to claims relating to its content will be borne by the authors. All authors equally contributed to this review. 


\section{Open Access}

This is an Open Access article that uses a funding model which does not charge readers or their institutions for access and distributed under the terms of the Creative Commons Attribution License (http://creativecommons.org/licenses/by/ 4.0) and the Budapest Open Access Initiative (http://www.budapestopenaccessinitiative.org/rea d), which permit unrestricted use, distribution, and reproduction in any medium, provided the original work is properly credited.

\section{REFERENCES}

1. BSBI List 2007. Botanical Society of Britain and Ireland. Archived from the original (xls) on 2015-01-25. Retrieved 2014-10-17. [Cited 2019 Mar 9]. Available from:

https://www.webcitation.org/6VqJ46atN?url=http://www. bsbi.org.uk/BSBIList2007.xls

2. Pelkonen V, Pirttila AM. Taxonomy and phylogeny of the genus Lilium. Floriculture ornamental biotech 2012; 6(2): 1-8.

3. World Checklist of Selected Plant Families (WCSP). Lilium martagon L., Sp. Pl.: 303 (1753). [Cited 2019 Mar 9]. Available from: https://wcsp.science.kew.org/namedetail.do?name_id=2 79985

4. Coombes AJ. The Hamlyn guide to plant names. London: Hamlyn, 1992; 207 p. ISBN, 600575454.

5. "Royal Curls". Encyclopedic Dictionary of Brockhaus and Efron: 86 vol. (82 vol. and 4 extra.). St. Petersburg, 1890-1907.

6. Ståhlberg S, Svanberg I. Sarana in Eurasian folk botany. Journal de la Société Finno-Ougrienne 2006; 91: 133 157.

7. Germplasm Resources Information Network. [cited 2019 Mar 9]. Available from: www. ars-grin.gov.

8. Plantarium. The determinant of plants on-line. Open Atlas of Plants and Lichens in Russia and Adjacent Countries. Lilium martagon taxons. [cited 2019 Mar 9]. Available from: $h$ ttp://www. plantarium.ru/

9. Ståhlberg S, Svanberg I. Gathering food from rodent nests in Siberia. J Ethnobiol 2010; 30(2): 184-202.

10. Znamensky IE. Plant Raw Materials. Part IV. Wild Edible Plants: Chemical and Technical Reference. Ed. prof. V.N. Lyubimenko. Moscow. Goskhimtekhizdat, 1932. Vol. 12.

11. Lundquist K. Lilium martagon L. Doctoral Thesis No. 2005:19 Faculty of Landscape Planning, Horticulture and Agricultural Science. Krolliljans introduktion och tidiga historia i Sverige intill år 1795 - $i$ en europeisk liljekontext.

12. Donetskaya E. Medicinal plants in everyday life, medicine, cosmetics. Description of plants, cultivation and collection, shelf life, indications, recipes, contraindications, cosmetics. Volume 4 , from $L$ to $O$.
Publishing house Veche. Moscow, 2017. Electronic Book, 88-89.

13. Harvey JH. Fritillaryand Martagon: Wild or Garden? Garden History 1996; 24(1): 30-38.

14. Mullabaeva EZ, Fatykhova AV. Some characteristics of coenopopulation Lilium martagon $L$. in the southern Urals. Bulletin of the Orenburg State University 2009; 6 (100): 258-260.

15. Jelitto L, Schacht W, Fessler A. Die FreilandSchmuckstauden. Ulmer; 1998; 683 p.

16. Gubanov IA, Krylova IL, Tikhonova VL. Wild-growing useful plants of the USSR. Ripol Classic; 1976; 63-64.

17. Becker A, Alix K, Damerval C. The evolution of flower development: current understanding and future challenges. Ann bot 2011; 107(9): 1427-1431.

18. Kuczyńska J, Sarosiek J, Szymańska E. Populacje Lilium martagon L. Acta Univ Wrastis/ 1985; 775: 155-178.

19. Truchan M, Sobisz Z. Characteristics of Lilium martagon L. population in Lasin Koszalinski (Western Pomerania). Roczniki Akademii Rolniczej w Poznaniu. BotanikaSteciana 2009; 13: 85-95.

20. Pupuleku B, Kapidani G, Kallajxhiu N, Naqellari P, Turku S. Palynological studies of pollen grains of Albania's endemic plant Festucopsis serpentini (CE Hubbard) Melderis and Lilium martagon L. in three different habitats. Natura montenegrina 2010; 9: 431-440.

21. Gürdal B, Demirci S, Özhatay N, Kaya E. Chromosome numbers of 9 taxa of Lilium (Liliaceae) from Turkey. Flora Mediterranea 2016; 26: 220.

22. Nawaschin S. Resultate einer revision der befruchtungsvorgänge bei Lilium martagon und Fritillaria tenella. Bulletin de l'Académie Impériale des Sciences 1898; 9 (4): 377-382.

23. Sargant $E$. The formation of the sexual nuclei in Lilium martagon. I. Oögenesis. Ann Bot 1896; 10(39): 445-477.

24. Sargant $E$. The formation of the sexual nuclei in Lilium martagon: II. Spermatogenesis. Ann Bot 1897; 11(42): 187-224.

25. Beattie DJ, White JW. Lilium-hybrids and species. The physiology of flower bulbs. Elsevier, Amsterdam; 1993; 423-454.

26. Richardson MM. Structural hybridity in Lilium martagon album× L. hansonii. J Genet 1936; 32(3): 411-450.

27. Lim KB, Barba-Gonzalez R, Zhou S, Ramanna MS, Van Tuyl JM. Interspecific hybridization in lily (Lilium): taxonomic and commercial aspects of using species hybrids in breeding. In: Jaime A., editor. Floriculture, ornamental and plant biotechnology, 1st edn. Japan, Global Science Books, Ltd.; 2008; Vol. 5; pp 138-145.

28. Persson HA, Lundquist $K$, Nybom H. RAPD analysis of genetic variation within and among populations of Turk's-cap lily (Lilium martagon L.). Hereditas 1998; 128 (3): 213-220.

29. Muratović E, Hidalgo O, Garnatje T, Siljak-Yakovlev S. Molecular phylogeny and genome size in European lilies (Genus Lilium, Liliaceae). Adv Sci Lett 2010; 3(2): 180189. 
30. Balode A. Diversity of the martagon lily (Lilium martagon L.) in Latvia. Vytauto Didžiojo universiteto Botanikos sodo raštai 2013; 17: 25-35.

31. Makarov AA. Herbal remedies of Yakut traditional medicine. Yakutsk, 1974; 35.

32. Kucherov EV. Wild food plants of Bashkiria and their use. Ufa, 1990; 68-69.

33. Flowering plants, their chemical composition, use. Plant resources of Russia and neighboring states: Family Butomaceae - Typhaceae. St. Petersburg: Science, 1994; 271

34. Pinder AR. Pyrrolidine, piperidine, and pyridine alkaloids Nat Prod Rep 1990; 7(5): 447-455.

35. Fatkhiev F, Samikov K, Shakirov R. Dynamics of the alkaloid content of Lilium martagon. Chem Nat Comp 1991; 26(4): 476-477.

36. Rossetti V. y-Methyleneglutamic acid in Lilium martagon. Planta med 1981; 41(02): 204-205.

37. Satou T, Mimaki Y, Kuroda M, Sashida Y, Hatakeyama $Y$. A pyrroline glucoside ester and steroidal saponins from Lilium martagon. Phytochemistry 1996; 41(4): 1225-1230.

38. Munafo Jr JP, Gianfagna TJ. Chemistry and biological activity of steroidal glycosides from the Lilium genus. Nat Prod Rep 2015; 32(3): 454-477.

39. Roshchina VV, Yashina AV, Yashin VA, Prizova NK. Models to study pollen allelopathy. Allelopathy J 2009; 23 (1): 3-24

40. Hartwell JL. Plants used against cancer. A survey Lloydia. 1967; 30: 379-436.

41. Mahmood K. Compositions comprising Lilium martagon extracts and uses thereof. United States Patent 2016; 9492492 Patent and Trademark Office.

42. Chehregani A, Kouhkan F. Diesel exhaust particles and allergenicity of pollen grains of Lilium martagon. Ecotoxicol Environ Saf 2008; 69(3): 568-573.

43. Harm SS, Choi JJ, Lee EM, Yu SH. Occurrence of leaf blight of lily caused by Botrytis elliptica. 한 국 원 예 학회 기 타 간 행 물 2006; 154.

44. Lawson RH. Detection, diagnosis and control of lily diseases. In II International Symposium on the Genus Lilium 2010; 900: 313-324.

45. Fisher JR. Identification of Lily symptomless virus infecting Lilium martagon 'Pink Taurade' in Ohio. Plant Health Prog 2013; 14(1): 45.

46. Poncarová-Vorácková Z, Fránová J, Válová P, Mertelik J, Navrátil M, Nebesárová J. Identification of phytoplasma infecting Lilium martagon in the Czech Republic. J Phytopathol 1998; 146(11-12): 609-612.

47. Guney K, Cetin M, Sevik H, Guney KB. Influence of germination percentage and morphological properties of some hormones practice on Lilium martagon L. seeds. Oxid commun 2016; 39(1): 466-474.

48. Guney K, Cetin M, Guney KB, Melekoglu A. The effects of some hormone applications on Lilium martagon $L$. germination and morpholgical characters. Pol J Environ Stud 2017; 26 (6): 2533-2538.
49. Bach A, Kedra M. Somatic embryogenesis of Lilium martagon L. in seedlings culture. Acta Biologica Cracoviensia. Ser Bot et Zool. Suppl 1997; 39(1): 47

50. Glamočlija U, Haverić S, Čakar J, Rahmanović $A$, Marjanović $D$. In vitro propagation of Lilium martagon $L$. var. cattaniae Vis. and evaluation of genotoxic potential of its leaves and bulbs extracts. Acta Biol Slov 2010; 53(2): 53-60.

51. Skorić M, Živković S, Savić J, Šiler B, Sabovljević $A$, Todorović S, Grubišić D. Efficient one-step tissue culture protocol for propagation of endemic plant, Lilium martagon Vis. Afr J Biotechnol 2012; 11 (8): 1862-1867.

52. Wang $Y$, Xue L, Lei J. Study on culture in vitro of scales in Lilium martagon var. pilosiusculum. $J$ Northeast Agric Univ 2017; 4: 5.

53. Karalija E, Trbojević S, Parić A. Somatic embryogenesis and in vitro plantlet regeneration of Lilium martagon $L$. var. cattaniae Vis. Biol Nyssana 2010; 1(1-2): 57-60.

54. Una G, Sanin H, Jasmina C, Anisa R., Damir M. In vitro propagation of Lilium martagon $L$. var. cattaniae Vis. And evaluation of genotoxic potential of its leaves and bulbs extracts. Acta Biol Slov 2012; 53: 53-60.

55. Rybczynski JJ, Gomolinska H. 6-benzyladenine control of the initial bulblets formation of wild lily Lilium martagon L. In III International Symposium on Growth Regulators in Ornamental Horticulture 1988; 251: 183-190.

56. Optiz E, Anderson NO, Younis A. Development of colored, non-vernalization-requiring seed propagated lilies. In XXIII International Eucarpia Symposium, Section Ornamentals: Colourful Breeding and Genetics 2009; 836: 193-198.

57. Lundqvist A. Four-locus S-gene control of self-incompatibility made probable in Lilium martagon (Liliaceae). Hereditas 1991; 114 (1): 57-63.

58. Anderson NO, Plattes A, Opitz E, Younis A. Transgressive segregant, interspecific hybrids between Lilium $\times$ formolongi and L. martagon with unique morphology. In II International Symposium on the Genus Lilium. 2010; 900: 181-187.

59. Proseviçius J, Strikulyte L. Interspecific hybridization and embryo rescue in breeding of lilies. Acta Univ Latv Biol 2004; 676: 213-217.

60. Lim KB, Van Tuyl JM. Lily. In Flower Breeding and Genetics. Springer, Dordrecht 2007; 517-537.

61. Bakhshaie M, Khosravi S, Azadi P, Bagheri H, van Tuyl JM. Biotechnological advances in Lilium. Plant Cell Rep 2016; 35(9): 1799-1826.

62. Marossy A. Wild plant species endangered through intensive harvest. In Nature Conservation Springer, Berlin, Heidelberg 2006; pp 65-67.

63. Ke,dra M, Bach A. Morphogenesis of Lilium martagon L. explants in callus culture. Acta Biol Cracov Bot 2005; 47(1): 65-73.

64. Urbaniec-Kiepura M, Bach A. Effect of pre-storage on Lilium martagon $L$. seed longevity following cryopreservation. CryoLetters 2014; 35(6): 462-472. 